\title{
Hukum dan Bahasa: Refleksi dan Transformasi Pemenuhan Hak Ekonomi, Sosial dan Budaya
}

\author{
James Reinaldo Rumpia \\ University of Lampung, Indonesia \\ jamesreinaldor@gmail.com
}

\author{
H. S. Tisnanta \\ University of Lampung, Indonesia \\ s.nymus@yahoo.com
}

\begin{abstract}
The regulation of economic, social and cultural rights is always intertwined with the language. A language has a significance in the dimension of the recognition of protection and the fulfillment of rights through the legal certainty of text. The text of the law is a commitment of rights fulfillment. Structure and understanding space of the text is directed to predict and reach the needs of the fulfillment of the rights. States in the context of the fulfillment of rights must be able to realize legal texts that are aligned and responsive. A legal text that favors the fulfillment of the civil rights, as well as reaching the dynamic that can reduce the fulfillment of rights. The text of the law through language that reflects and transforms elements of the economic, social, and cultural right, ie freedom, availability, accessibility, and conformity. But often the language and legal text formulated are inconsistent and uncertain. Language as a tool of transformation of rights it becomes a tool that shackles. This issue requires an understanding of intertextuality with respect to the text of the law. One of the strategies is by mapping the elements in the text of the law, which include: principles, standards, and concepts as a medium for the facilitation of values and legal goals. The dichotomy of this element is intended to understand relationships that can affect the accuracy of meaning to reflect the purpose of formulating the text of the law. The weakness of legal texts can thus be reconstructed in responsive, progressive and communicative spaces and structures.
\end{abstract}

KEYWORDS: Language, Law Text, Reflection, Transformation, Socio-Economic and Cultural Rights.

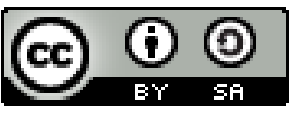

Copyright $\odot 2018$ by Author(s)

This work is licensed under a Creative Commons Attribution-ShareAlike 4.0

International License. All writings published in this journal are personal views of the authors and do not represent the views of this journal and the author's affiliated institutions.

\section{HOW TO CITE:}

Rumpia, James Reinaldo \& H. S. Tisnanta. "Hukum dan Bahasa: Refleksi dan Transformasi Pemenuhan Hak Ekonomi, Sosial dan Budaya" (2018) 5:2 Lentera Hukum 247-264.

Submitted: April 30, 2018 Revised: May 03, 2018 Accepted: July 16, 2018

1 Naskah ini pernah dipresentasikan di Konferensi SEPAHAM 2017 dengan beberapa revisi yang berasal dari proses konferensi dan review pada jurnal ini. 


\section{PENDAHULUAN}

Dimensi pemenuhan hak sosial-ekonomi berada dalam formalitas kerangka regulasi. Kerangka regulasi menentukan dan merefleksikan sejauh mana tanggung jawab negara dalam pengakuan, perlindungan, dan pemenuhan hak warga negaranya. Tanggung jawab negara tersebut dimaksudkan untuk menciptakan kemandirian, kebebasan dan kesejahteraan bagi warga negara. James A Griffin menyebutkan bahwa hak asasi manusia mengarah pada satu atau ketiga tujuan sekaligus, yakni: kemandiriaan, kebebasan, dan kesejahteraan autonomy. ${ }^{2}$ Hak sosial ekonomi pada umumnya akan berfokus pada kesejahteraan di mana kesejahteraan tidak akan lepas dari kebebasan dan kemandirian. Warga negara tidak akan sejahtera jika mereka terbelenggu dan masih bergantung pada pihak-pihak lain. Usaha perwujudan nilai dan tujuan pemenuhan hak ini, bukan hanya dapat dilihat pada cara bekerjanya sebuah regulasi. Namun juga harus diperhatikan dalam bekerja formulasi bahasa.

Kerangka regulasi merupakan kompilasi konsep atau pengertian yang disusun melalui bahasa. Andrei Marmor menyebutkan bahwa bahasa membangun konsepsi dari klasifikasi, menyusun taksonomi dari berbagai aspek yang ada dalam aktivitas sosial, ataupun mengajak orang-orang dalam kondisi tertentu. ${ }^{3}$ Ini menegaskan bahwa hukum membutuhkan konsep-konsep sebagai struktur dan ruang pemahaman. Pada sisi lain, konsep ini berkedudukan secara praktis sebagai medium prediksi dan jangkauan atas prilaku masyarakat dalam kepastian formal. Konsep yang dibangun demi fungsifungsinya tidak dapat dilepaskan atas kaidah bahasa. Semantik (arti tanda), sintaktik (relasi bentuk/struktur tanda) dan pragmatik (tujuan tanda), sebagaimana diungkap Brugink tidak dapat dipisahkan satu sama lain. ${ }^{4}$ Arti bahasa dibangun di atas struktur bahasa, dan dibangun demi tujuan tertentu. Hal yang juga diperhatikan atas kaidah bahasa adalah hukum membutuhkan kaidah bahasa yang khusus.

Kaidah bahasa yang dibutuhkan hukum, cenderung menampilkan dominasi pada sisi teknis. Bahasa untuk hukum membutuhkan bahasa yang mampu menjamin terselenggaranya perilaku masyarakat, sesuai dengan kaidah dan cita hukum yang dikehendaki. Hal ini diwujudkan oleh bahasa untuk hukum atau dikenal sebagai bahasa hukum melalui sisi daya paksanya. Bahasa hukum diungkap oleh Andrew Halpin sebagai berikut:

So, the basic characteristic of legal language found in both the crude and sophisticated forms of legal propositions is that it expresses a requirement of conduct from a person. It tells people what to do. With some degree of authority. ${ }^{5}$

James Griffin, On Human Rights, (New York: Oxford University Press, 2008), hlm. 95.

Andrei Marmor, Social Convention from Language to Law, (New Jersey: Princetown University Press, 2009), hlm. 95.

4 JJ. Brugink, Refleksitentang Hukum Pengertian-Pengertian Dasar dalam Teori Hukum, penerjemah: B. Arief Sidharta, (Bandung: Citra Aditya Bakti), hlm. 38.

5 Andrew Halpin, Language, Truth and Law, dalam Michael Freeman dan Fiona Smith, Law and Language Current Legal Issue Volume 15, (United Kingdom: Oxford University Press, 2013), hlm 64 
Karakter dari bahasa hukum ditemukan dari bentuk preposisi hukum yang mengekpresikan kehendak dari seseorang untuk melakukan sesuatu. Hal ini diwujudkan melalui derajat otoritas tertentu. Rekayasa perilaku masyarakat diarahkan melalui bahasa direktif. Bahasa yang mendorong masyarakat, untuk tunduk dan patuh dalam kaidah-kaidah yang telah ditetapkan. Daya paksa yang dimiliki ini juga bergantung pada kejelasan dan ketegasan formulasi bahasa. Hal ini menentukan pada pengakuan, perlindungan dan pemenuhan hak.

Tulisan ini membahas tentang kepastian yang disediakan teks hukum dalam kerangka regulasi dalam pemenuhan hak sosial ekonomi budaya. Uraian terhadap hal ini akan dimulai dari refleksi terhadap relasi fungsional teknis antara bahasa dan kerangka regulasi. Adapun uraian selanjutnya berkenaan dengan refleksi terhadap keterbatasan bahasa dalam formulasi. Bahasa seringkali diketahui mengalami kemenduaan atau ambigu dalam menyampaikan makna yang dikehendaki. Hal ini dapat tergambar dari pilihan term maupun penempatan konstruksi yang tidak tepat dalam mempertegas konsep hak dan tanggung jawab negara. Bahasa yang seharusnya menjadi ekpresi, informasi, dan direksi terhadap jaminan hak, namun justru menjadi sumber ketidakpastian yang membelenggu pemenuhan hak dalam formalitas.

\section{DIMENSI FORMAL-TEKNIS KERANGKA REGULASI}

Dimensi formal tidak dapat diabaikan dalam persoalan pemenuhan hak sosial ekonomi. Sebuah kenisyaan bahwa momen politik idiil disebutkan oleh Meuwissen yang memuat nilai dan tujuan akan bersanding dengan momen teknikal. ${ }^{6}$ Prinsip kehidupan yang layak misalnya dalam Deklarasi Universal HAM memerlukan aspek formal, untuk berlaku secara sah di masyarakat. ${ }^{7}$ Aspek formal menjadi permulaan atas komitmen penyelenggaraan dan pemenuhan hak oleh negara. Momen teknikal yang dimaksud misalnya dapat dilihat pada ketentuan penyusunan peraturan perundang-undangan. Materi yang hendak diatur atau dijamin, harus tunduk pada kaidah yang tepat untuk dapat diaplikasikan. Namun momen teknis bukan berarti hanya terbatas pada rumusan naskah akademik, rapat pembahasan, hingga penetapan.

Momen teknis dapat diartikan pada usaha bertahap, penyusunan materi prinsip hingga sampai pada kenyataan masyarakat. Materi yang disusun harus benar-benar dapat merefleksikan semangat/prinsip pemenuhan hak. Kondisi ini bahkan menjadi perhatian khusus dalam Komentar Umum Nomor 9 Konvenan Internasional Hak Sosial Ekonomi Budaya tentang pelaksanaan konvenan di dalam negeri. Pendekatan negara dalam menciptakan ukuran-ukuran menentukan untuk memunculkan kondisi khusus yang dibutuhkan untuk mewujudkan nilai dan tujuan dalam konvenan. ${ }^{8}$ Posisi negara

6 Meuwissen, Tentang Pengembangan Hukum, Ilmu Hukum, Teori Hukum, dan Filsafat, terjemahan B Arief Sidharta, (Bandung: Refika Aditama, 2013), hlm 10.

7 Deklarasi Universal Hak-Hak Asasi Manusia Pasal 25. Lihat juga Kovenan Internasional Hak Sosial Ekonomi dan Budaya.

8 Komentar umum No 9 Pelaksanaan Kovenan di Dalam Negeri dalam Komentar Umum Konvenan Internasional Hak Sipil Politik-Hak Ekonomi Sosial Budaya, (Jakarta: Komnas Ham, 2009), hlm 136. 
dimaksudkan untuk bersikap afirmatif merespon ketertinggalan dan keterbatasan yang mungkin menghalangi pemenuhan hak. Di sisi lain, ukuran/standar dimaksudkan sebagai rangkaian proses yang konsisten. Dalam perwujudan hak ekonomi misalnya disebutkan oleh Shareen Hertel dan Lanse Minkler tidak dapat diwujudkan secara tiba-tiba namun dapat diwujudkan secara progresif bergantung ketersediaan sumber daya dan pembangunan. ${ }^{9}$ Penciptaan standar merupakan langkah awal, dari transplantasi hak. ${ }^{10}$ Standar berkedudukan sebagai cara melaksanakan prinsip dengan pertimbangan-pertimbangan ideal. Tolok ukur terpenuhinya prinsip juga dengan demikian, berada di dalam standar. Sekalipun standar terbagi ke dalam standar kumulatif (pemenuhan secara keseluruhan poin), dan standar partikular (cukup salah satu poin terpenuhi). Namun konteks pemenuhan hak ekosob menuntut terpenuhinya standar secara menyeluruh.

Pemenuhan hak sosial ekonomi, adalah satu kesatuan proses yang memberikan dan menyedian kebebasan dan kemandirian bagi pemegang hak, maka secara berkelanjutan standar menjadi kesempatan untuk memperbaiki kualitas kehidupan. Contoh standar kumulatif tentang prinsip hidup layak warga negara. Prinsip hidup layak dapat dikatakan telah terpenuhi jika tersedia dan terpenuhinya akses kesehatan; tersedia dan terpenuhinya aspek ekonomi rakyat; tersedia dan terpenuhinya akses kesehatan rakyat. Ketiga poin tersebut wajib dipenuhi untuk mencapai kehidupan layak yang ideal. Kedudukan standar dalam kondisi demikian tidak cukup untuk dapat memberikan kepastian pelaksanaan prinsip dalam lapangan kenyataan masyarakat.

Standar pada sisi lain perlu dibangun dalam kerangka relasional, dan kesatuan. Keberadaan standar sebagai ukuran pemenuhan hak memerlukan kesatuan dalam bentuk atau konsep. Konsep digambarkan sebagai medium, relasional dan kesatuan dari standar. B Arief Sidharta menyebutkan konsep sebagai representasi atau perwakilan objek yang ada di luar subjek. ${ }^{11}$ Subyek dan objek dipisahkan sebagai yang mengamati dan teramati. Kerangka konsep sebagai struktur pandang subjek, terhadap objek yang disusun. Konsep dapat dipahami dan dijelaskan dalam dua wujudnya, yakni melalui definisi dan klasifikasi. Definisi menggambarkan tentang karakter dari konsep yang hendak dijelaskan. ${ }^{2}$ Sebagai contoh ciri-ciri dari hak sosial ekonomi adalah bertujuan mencapai hidup yang layak; tanggungjawab negara; pengakuan; perlindungan; relasi antar manusia. Pada sisi lain yang dimaksud dengan klasifikasi adalah proses pemilihan dalam bagian-bagian tertentu. ${ }^{13}$ Hak sosial ekonomi terdiri

9 Shareen Hertel dan Lanse Minkler, Economic Right the Terrain dalam Shareen Hertel dan Lanse Minkler, Economic Rights Conceptual, Measurement, and Policy Issue, (United State: Cambridge University Press, 2007), hlm 16.

10 Relasi prinsip, standar, konsep dan hukum dapat dilihat pada pembahasan yang dilakukan oleh G.W Paton, Textbook of Jurisprudence, second edition, (London: Oxford University Press, 1955), hlm 175. Lihat Adapun juga dapat dilihat dalam pembahasan yang dilakukan oleh Satjipto Raharjo tentang relasi asas, standar, pengertian, dan peraturan. Lihat juga Satjipto Raharjo, Ilmu Hukum, (Bandung: Citra Aditya Bakti, 2014), hlm 41.

Il B Arief Sidharta, Logika Sebuah Langka Mengenal Medan Telaah, (Bandung: Refika Aditama, 2008), hlm 21.

12 Ibid, hlm 24.

13 Ibid, hlm 26. 
atas hak atas pendidikan; hak atas pekerjaan; hak atas kesehatan; hak atas jaminan sosial. Klasifikasi juga dimaksudkan untuk membagi tanggung jawab dan kewenangan atas institusi penyelenggara.

Gagasan tentang konsep baik dijelaskan dalam definisi, maupun dengan klasifikasi yang harus diperhatikan adalah ruang pemahamannya. Konsep pada sisi teknis menurut G.W Paton yakni tentang penetapan terhadap definisi dan luas aplikasi. ${ }^{14}$ Selaras dengan G.W Paton membahas tentang luasan aplikasi, JJ Brugink melihat dari intensi (keseluruhan ciri) dan ektensi (obyek yang tercakup). Brugink mendalilkan bahwa. ${ }^{15}$ Pertama, intensi menentukan ekstensi. Keseluruhan ciri menentukan luasan dari obyek yang tercakup. Sebagai contoh jaminan sosial adalah salah satu bentuk perlindungan sosial untuk menjamin seluruh rakyat agar dapat memenuhi kebutuhan dasar hidupnya yang layak. Pengertian tersebut menentukan bahwa yang termasuk adalah bentuk-bentuk perlindungan sosial, untuk seluruh rakyat, tujuan sekundernya pemenuhan kebutuhan dasar dan tujuan primernya hidup yang layak. Kedua, intensi berbanding terbalik dengan ekstensi. Semakin banyak ciri yang ditetapkan maka semakin sedikit objek yang tercakup di dalamnya. Masih pada contoh jaminan sosial, namun ditambah dengan perlindungan sosial oleh pemerintah. Perubahan ini berdampak pada perlindungan sosial hanya dapat dilakukan oleh pemerintah, bukan oleh pihak lain. Luas dibatasi dengan ciri-ciri yang spesifik, sehingga mengurangi wilayah aplikasi dari konsep.

Konsep yang dibangun tidak lepas dari kenyataan masyarakat. Usaha membangun bukanlah representasi kenyataan sosial-masyarakat yang sesungguhnya dengan kenyataan sosial masyarakat. Kenyataan dalam pandangan Satjipto Raharjo direduksi dalam konsep-konsep artifisial untuk menggambarkan kebutuhan rumusan. ${ }^{16}$ Kondisi asumtif ini menjadikan konsep dalam rumusannya dapat mengalami kesulitan. Term (kumpulan kata) dalam membentuk konsep, sebagai contoh merupakan dilema tersendiri. Kriterium dari term dapat berasal dari berbagai landasan seperti etika, moralitas, filosofi, budaya, sejarah bangsa dan negara. Keberagaman dari landasan ini, tidak jarang menimbulkan perdebatan. ${ }^{17}$ Kondisi perdebatan landasan terhadap rumusan hak, ditanggapi oleh James Griffin dengan pendapat sebagai berikut:

We do not know. The term 'human right' is nearly criterionless. There are unusually few criteria for determining when the term is used correctly and when incorrectly-and not just

14 G.W Paton, Textbook of Jurisprudence. supra note 9, hlm 177.

15 JJ. Brugink, Refleksi Tentang Hukum Pengertian-Pengertian Dasar dalam Teori Hukum, supra note 3, hlm 54-55.

16 Sajtipto Raharjo, Penafsiran Hukum yang Progresif, Makalah untuk mahasiswa PDIH UNDIP dalam Mata kuliah Ilmu Hukum dan Teori Hukum, Pleburan, 20 Januari 2005, hlm 5.

17 Perdebatan yang terjadi dalam rumusan hak asasi manusia yang terjadi pada theorist dan praktisi antara lain: 1) hak asasi dengan standar minimal ataupun non-minimal; 2) berfungsi sebagai justifikasi paksaan internasional atau tidak; dan 3) proteksi terhadap kepentingan manusia atau kapasitas manusia. Lihat Marcus Arvan, A Better, "Dual Theory of Human Rights" 45: 1 Philosophical Forum hlm 22. 
among politicians, but among philosophers, political theorists, and jurisprudents as well. The language of human rights has, in this way, become debased. ${ }^{18}$

Istilah HAM hampir tanpa kriteria. Ada beberapa kriteria yang bahkan tidak dapat ditentukan atas dasar benar maupun salah. Hal ini tidak terjadi hanya pada politisi, namun pada filsuf, ahli politik dan hukum. Term dari hak itu sendiri diungkap oleh Griffin hampir mustahil, karena ketiadaan kriteria pasti. Keanekaragaman landasan formulasi ini, dalam kenyataannya dapat dikesampingkan. Kepuasan untuk semua pandangan akan hak bukanlah masalah yang patut diperpanjang. Griffin mengingatkan kembali pada urgensi dari term yang disusun untuk praktikal. ${ }^{19}$ Term sebagai bagian dari definisi dan konsep, diperlukan untuk mengakui, dan menjaga keberlangsungan hak. Tentu tanpa konsep, lalu bagaimana untuk menjamin hak yang dimaksud. Hal ini yang menjadi alasan mengapa lebih diutamakan dalam membuat standar-standar hak dalam definisi. Semua perjalanan rumusan tersebut mulai dari prinsip hingga pada konsep, berakhir pada teks hukum modern.

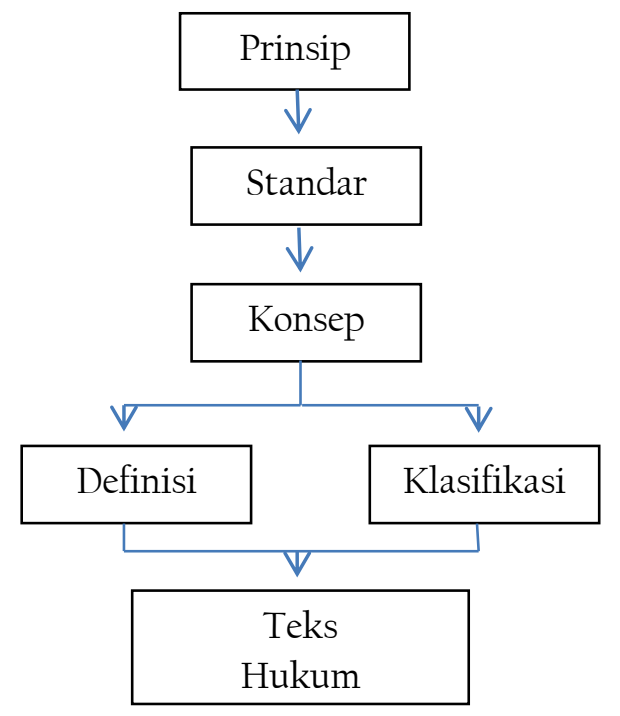

Hukum modern menjadi medium kepastian terhadap keberterimaan dan keberlangsungan definisi. Komitmen untuk menjaga keberlangsungan tersebut diwujudkan melalui transformasi hak sosial-ekonomi, menjadi legal rights.. Hak yang diakui dan dijamin negara melalui hukum. Perubahan status demikian, menegaskan kedudukan hak yang tidak terlepas dari kewajiban. Keberadaan hak pada seorang individu berarti kewajiban pada individu lainnya untuk menghormati hak tersebut. Gagasan relasi hak dan kewajiban, pada tahap lanjut dapat ditemukan dalam pemikiran HLA Hart. Legal rights beserta duties dalam pandangan HLA Hart diberikan sumber daya

18 James Griffin, On Human Rights, supra note 1, hlm 14-15.

19 Ibid, hlm 19. Urgensi demikian dalam bahasa Irving M Copi, Kenneth, dan Cohen sebagai operational definition, yakni mendeskripsikan beberapa aksi atau operasi dengan term (kumpulan kata-kata). Lihat Irving M Copi, Carl Cohen, Kenneth McMahon, Introduction to Logic, Pearson New International Edition, (United State: Pearson Education Limited, 2014), hlm 97. 
koersif, untuk menjamin kebebasan individual dan membatasi diri mereka untuk memiliki sumber daya koersif sendiri. ${ }^{20}$ Saat demikian, yang dimaksud oleh Joseph Raz sebagai bekerjanya fungsi sosial langsung dari hukum. ${ }^{21}$ Hak yang telah berada dalam naungan sumber daya koersif, akan bebas dari segala ancaman yang sifatnya diskriminatif. Ketika sudah terbebas dari ancaman, maka ekplorasi dan usaha mengaktifkan fitur-fitur hak dapat terlaksana. Daya paksa pada tahap minimal setidaknya dapat menciptakan kesetaraan prosedural, terhadap akses hak sosialekonomi dari warga negara. Sebagai contoh jaminan akses kesehatan yang akan diterima, harus melewati serangkaian persyaratan dan prosedur yang sama bagi setiap orang. Tanpa memenuhi persyaratan maka akses kesehatan tidak akan dipenuhi. Namun gagasan daya paksa ini, sesungguhnya bukan hanya dimaksudkan bagi individu warga negara saja, ataupun dimaksudkan melindungi dari diskriminasi.

Gagasan terhadap hak melampaui legislasi dengan daya paksa yang tinggi. Kewajiban negara secara aktif, tidak hanya menciptakan keseteraan melalui prosedurprosedur ataupun menjamin perlakuan nondiskriminatif. Hal ini terkhusus pada hak sosial ekonomi, yang tidak cukup hanya bersandar pada perlindungan dari ancaman saja. Hak sosial-ekonomi merupakan hak yang terus berkembang secara wacana dan kondisi, maka memerlukan penanganan yang juga mengikuti perkembangan zaman. Sabine, Mark Gibney, dan Steven C Poe menegaskan tentang jaminan hak sosial, ekonomi adalah sifatnya positive obligation. ${ }^{22}$ Hak yang harus dipenuhi melalui keterlibatan aktif negara. Hak sosial-ekonomi dalam pengertiannya merupakan hak yang membutuhkan pendekatan secara meluas. Pendekatan meluas terhadap kewajiban negara didesain oleh Persatuan Bangsa-Bangsa (PBB) dalam 3 nilai dasar yaitu to respect, to protect dan to fulfill. ${ }^{23}$ Negara dengan demikian tidak hanya berkewajiban melindungi warga negara dari sikap dan tindakan diskriminasi. Namun juga memastikan bahwa hak sosial-ekonomi diakui, dilindungi, dan dipenuhi. Hal ini misalnya dapat dipastikan dari komitmen mekanisme, yang tersedia dalam kerangka regulasi. Eksistensi pengakuan hak hanya sebatas angan-angan di atas kertas, ketika mekanisme relasi tanggung jawab tidak jelas. Aspek mekanisme mewakili tata cara yang memungkinkan hak sampai pada pemegang hak. Pasal 45 Undang-Undang Nomor 7 Tahun 2016 tentang Perlindungan dan Pemberdayaan Nelayan, Pembudidaya Ikan dan Petambak Garam, menyebutkan bahwa kegiatan pemberdayaan harus memperhatikan keterlibatan dan peran perempuan. Rumusan ini seakan memberikan harapan bahwa ada pengakuan yang tegas terhadap peran perempuan. Namun yang terjadi adalah dalam pasal-pasal berikutnya tidak dijelaskan sama sekali tentang sejauh mana tanggung jawab pemberdayaan yang dimaksud. Rumusan ini tidak menetapkan kewajiban dan tanggung jawab negara dalam pemenuhan hak perempuan. Padahal jika

20 HLA Hart, Concept of Law (Second Edition), (Oxford: Oxford University Press, 1997), hlm 269.

21 Joseph Raz, Authority of Law Essay on Law and Morality, (New York: Oxford Press, 1979), hlm 167.

22 Sabine C Carey, Mark Gibney, dan Steven C Poe, The Politics of Human Rights The Quest of Dignity, (New York: Cambridge University Press, 2010), hlm 49.

23 United Nation, Economic Cultural and Social Rights Handbook for National Human Rights Institution, (New York: United Nation, 2005), hlm 15-18. 
merefleksikan pada konteks hak ekosob, maka kebutuhan pemenuhan hak harusnya melampaui aspek pengakuan dan perlindungan.

Daya paksa dari hukum yang telah disebutkan, merupakan instrumen terluar untuk mengawal nilai-nilai hak tetap berada dalam kepastian pelaksanaan. Hukum memberikan kepastian tidak hanya dari luar manusia, yakni bagaimana perilaku manusia direkayasa sesuai dengan tujuan hukum. Manusia dan hubungan kausalitas (tertib kehidupan), melalui positivisasi menurut Soetandyo dapat diwujudkan secara pasti. $^{24}$ Ketika telah ditetapkan dalam hukum, relasi antar perilaku sudah pasti dapat diprediksi. Kesalahan dan kegagalan dari rekayasa bahkan dimungkinkan dapat diprediksi. Relasi hukum dan hak lebih dapat dikatakan, merupakan relasi imajinatif dan konkrit. Hukum menciptakan asumsi ke depan, dan juga mempengaruhi cara pandang terhadap hak.

Hans Kolstad menyebutkan bahwa relasi hukum dan hak, dapat berupa proses dan penilaian yang adil serta rehabilitasi (perubahan) terhadap masyarakat. ${ }^{25}$ Cara pandang terhadap hak dalam hal ini bergantung dari hukum yang menjaminnya. Konsep subsidi untuk orang miskin dalam suatu aturan hukum misalnya membangun paradigma bagi penyelenggara, masyarakat, dan orang miskin, bahwa untuk memenuhi hak orang miskin adalah melalui subsidi. Rekayasa yang dibangun demikian, bahkan dianggap kebenaran yang baku. Ketika tiada subsidi yang pasti dan berkelanjutan, maka hak orang miskin tidak terpenuhi. Ekpresi dalam simbol-simbol bahasa menjadi suatu hal yang esensial, dalam menentukan konteks jaminan hak. Bahasa menjadi perlambang komitmen atas pengakuan, perlindungan, dan pemenuhan hak.

\section{BAHASA DAN DILEMA RUMUSAN HAK SOSIAL, EKONOMI, DAN BUDAYA}

Bahasa menjadi konsekuensi logis, atas keberlangsungan dan jaminan hak sosialekonomi. Kesadaran demikian berasal dari kedudukan bahasa, dalam kerangka regulasi. Bahasa menjadi sisi terluar perwujudan konsep, pada realitas di masyarakat. Tugas dan kedudukan bahasa untuk hukum tidak dapat disamakan dengan bahasa pergaulan sehari-hari. Pergaulan sehari-hari tidak mempersoalkan masalah daya paksa, daya ikat, dan kepastian. Bahasa pergaulan hanya berfokus pada tersampaikannya informasi. Kemungkinan bahwa informasi tersebut akan dituruti dan diikuti sebagai aksi, merupakan persoalan masing-masing individu. Hukum membutuhkan bahasa yang dapat menjamin, informasi yang diberikan dapat dipahami dan dituruti. Fungsi bahasa untuk hukum sebagaimana diungkap Christopher Hutton, adalah stabilisasi terhadap operasional hukum. ${ }^{26}$ Hukum menghendaki rekayasa perilaku sebagai usaha

24 Soetandyo Wignjosoebroto, Pergeseran Paradigma dalam Kajian-Kajian Sosial dan Hukum, (Malang: Setara Press, 2013), hlm 117.

25 Hans Kolstad, "The Welfare State System Confronted with The Human Rights Principles" (2015) 37:2 Social Development Issues-International Consortium for Social Development, hlm 8.

26 Christopher Hutton, Language, Meaning and The Law, (Edinburg: Edinburg University Press, 2009), hlm 13. 
mewujudkan tujuan atau cita hukum. Dengan demikian, bahasa untuk hukum cenderung diwujudkan dalam bahasa perintah, dibanding dengan bahasa ekpresi dan informasi. ${ }^{27}$ Kecenderungan lainnya adalah sisi teknis dari bahasa yang ditampilkan untuk menjawab kebutuhan hukum.

Bahasa teknis untuk hukum seringkali disebutkan sebagai bahasa hukum. Setiap penyusunan peraturan perundang-undangan, harus tunduk pada kaidah tata bahasa khusus. Pada konteks pembentukan peraturan perundang-undangan, dikenal bahasa hukum dalam lampiran Undang-Undang Nomor 12 Tahun 2011 tentang Pembentukan Peraturan Perundang-undangan. Bahasa hukum disebutkan memiliki enam cirri diantaranya lugas dan pasti, bercorak hemat, objektif, baku, definisi atau batasan cermat, dan kata bermakna tunggal atau jamak dirumuskan dalam bentuk tunggal. ${ }^{28}$ Formulasi yang ada nanti diharapkan tidak menimbulkan makna ganda. Kaidah baku dalam ketentuan tentang bahasa ini yang menjaga makna dari kekaburan dan ketidakjelasan makna. Ketika bahasa sudah dapat konsisten menjalankan kaidah baku ini, maka kepastian makna diasumsikan akan terjamin. Cita hukum yang dibingkai dalam peraturan akan terwujud dan merekayasa masyarakat dalam ketertiban.

Harapan dan tujuan formalitas bahasa hukum melupakan keberadaan dirinya dalam realitas masyarakat yang cair. Fokus pada formalitas dan teknisnya, justru menimbulkan keraguan atas kepastian yang dicita-citakan. Bahasa hukum sebagaimana diungkap oleh Olga Burukina memiliki lima kontradiksi yaitu ${ }^{29}$ kontradiksi linguistik, kontradiksi berasal dari fenomena sosial, kontradiksi dalam fenomena kultural, kontradiksi dalam diskursus hukum, ${ }^{30}$ bahasa hukum mengalami kontradiksi ketika berhadapan dengan transplantasi hukum. ${ }^{31}$ Kontradiksi yang dialami oleh bahasa hukum inilah, yang kemudian menjadikan makna yang hendak disampaikan menjadi kabur atau ambigu. Satjipto Raharjo menyebutkan setidaknya ada tiga cacat akibat kemenduaan. ${ }^{32}$ Pertama, kemenduaan semantik, ketika kata dirumuskan terlalu umum. Kedua, kemenduaan sintaktik, yang disebabkan penggunaan kata-kata "atau", "dan", "semua. Ketiga, maksud yang disampaikan pembuat undang-undang tidak jelas. Kondisi demikian bukan hanya membuat hak tidak terjamin, namun juga membahayakan hak untuk dilanggar atas pembenaran normatif.

Pengantar dilema bahasa, menjadi awal pembahasan terhadap dimensi hak sosialekonomi, yang berada dalam teks hukum. Teks hukum yang dimaksud, akan difokuskan pada dua undang-undang, yakni Undang-Undang No 13 Tahun 2011 tentang

27 B. Arief Sidharta, Pengantar Logika... hlm 128.

28 UU No 12 Tahun 2011 tentang Pembentukan Peraturan Perundang-undangan. Contoh lain ketentuan bahasa hukum misalnya di Amerika. American Bar Association menyebutkan setidaknya 4 (empat) ketentuan: mengorganisir untuk kenyamanan pembaca, menggunakan bahasa yang langsung dan mudah dipahami, menulis dalam kalimat pendek dan menggunakan kalimat aktif, serta menggunakan peraga pembantu (format tanya jawab, tabel, daftar vertikal, dan memfasilitasi kejelasan). Dapat diakses dalam http://www.plainlanguage.gov/populartopics/regulations/aba.cfm.

29 Olga Burukina, "Legal Language: A Realm of Contradiction" (2012) 4: 2 Journal Contemporary Readings in Law and Social Justice, hlm 721-722.

30 Ibid, hlm 722.

31 Ibid.

32 Satjipto Raharjo, Ilmu Hukum, (Bandung: Citra Aditya Bakti, 2014), hlm 98. 
Penanganan Fakir Miskin ${ }^{33}$ dan Undang-Undang No 20 Tahun 2003 tentang Sistem Pendidikan Nasional. $^{34}$ Kedua undang-undang dipilih sebagai contoh karena kedudukan erat dengan pemenuhan kehidupan yang layak bagi warga negara. Kajian terhadap kedua undang-undang ini akan melihat pada pilihan kata dalam bahasa. Bahasa yang diformulasikan telah cukup merefleksikan cita-cita pemenuhan hak, atau justru menciptakan kebimbangan terhadap jaminan hak. Jika HAM memang penting, maka akan ideal jika dirumuskan dalam hak yang spesifik. ${ }^{35}$ Komitmen dan tanggung jawab terhadap hak akan terlihat dari spesifikasi formulasi.

Penulis menambahkan dalam konteks bahasa seharusnya bahasa yang disusun merupakan bahasa yang mampu menunjukkan keberpihakannya kepada pemegang hak dan merespon gejala-gejala yang mungkin dapat mengganggu pemenuhan hak. Dengan demikian, bahasa dalam teks hukum bukan bahasa yang dengan formalitasnya justru membelenggu ragam kondisi sosial, politik dan ekonomi di masyarakat. Namun bahasa yang mampu membangun interelasi dan koherensi, antara berbagai prapemahaman atau label kultural maupun konteks dan kebutuhan pemenuhan hak masyarakat. Hal ini diwujudkan dengan keberadaan bahasa yang mampu merefleksikan dan mentransformasikan standar-standar pemenuhan hak ekobsob yang meliputi kebebasan, ketersediaan, keteraksesan, dan kebersesuaian. Berikut ini penjelasan tentang empat standar tersebut:

\section{A. Kebebasan}

Aturan formal dimaksudkan untuk menjelaskan sejauh mana tanggung jawab dan komitmen negara untuk menjamin hak. Kebebasan yang dibelenggu kekuasaan melalui aturan formal boleh juga dipahami, sebagai cara sebuah kebebasan untuk dapat eksis atau dalam pandangan Ernesto Laclau sebagai paradox kebebasan dan kekuasaan. ${ }^{36}$ Namun bukan berarti dalam konteks pemenuhan hak berarti negara juga membatasi cara masyarakat untuk memenuhi hak ekosob. Pola demikian hanya menciptakan ketergantungan yang semakin memiskinkan kemandirian warga negara, untuk mencapai kualitas hidup yang berkeadilan sosial bagi mereka. Maka tugas negara adalah membebaskan golongan rentan dan lemah dari ketergantungan. ${ }^{37}$

\section{B. Ketersediaan}

33 Undang-Undang Nomor 13 Tahun 2011 tentang Penanganan Fakir Miskin (Lembaran Negara Republik Indonesia Nomor 83 Tahun 201l, Tambahan Lembaran Negara Republik Indonesia Nomor 5235 Tahun 2011).

34 Undang-Undang Nomor 20 Tahun 2003 tentang Sistem Pendidikan Nasional (Lembaran Negara Republik Indonesia Nomor 78 Tahun 2003, Tambahan Lembaran Negara Republik Indonesia Nomor 4301 Tahun 2003).

35 Amartya Sen, "Element of a Theory of Human Rights" (2004) 32: 4 Philosophy and Public Affairs hlm 345.

36 Ernesto Laclau, Deconstruction, Pragmatism, and Hegemony, dalam Simo Crithley et all, Deconstruction and Pragmatism, (New York: Routledge, 1996), hlm 54.

37 Frans Magnis Suseno, Etika Politik Prinsip Moral Dasar Kenegaraan Moderen, cetakan ke 8, (Jakarta: Pt Gramedia Pustaka, 2016), hlm 434. 
Negara menjamin bahwa terpenuhinya kerangka pemenuhan hak, merupakan komitmen untuk menyediakan kebutuhan. Kebutuhan yang dimaksud seperti fasilitas, institusi, lembaga, maupun organ yang mampu menunjang pemenuhan hak ekosob. Dalam konteks pemenuhan hak pendidikan misalnya, unsur ketersediaan berkaitan dengan bagaimana negara mampu menyediakan fasilitas pendidikan untuk menunjang program pendidikan dengan jumlah yang cukup dan tepat. ${ }^{38}$ Negara dalam teks hukum harusnya menegaskan kewajiban untuk memenuhi hak, tanpa terhambat oleh keterbatasan terhadap ketersediaan sumber daya.

\section{A. Keteraksesan}

Sumber daya yang disediakan juga harus mampu diakses oleh setiap warga negara. Kelemahan dan keterbatasan sebagai akibat persaingan struktur sosial masyarakat maupun pasar bebas, tidak boleh menjadi alasan untuk membiarkan adanya golongan yang tidak mendapatkan akses atas hak ekosob. Dalam hal ini keteraksesan menekankan pada prinsip nondiskriminatif..$^{39}$ Peran negara yang paling signifikan adalah dengan menciptakan kebijakan dan kerangka hukum afirmatif, yang merespon kebutuhan dan kelemahan yang mengakibatkan golongan tertentu menjadi terhambat dalam mengakses hak mereka.

\section{Kebersesuaian}

Peran negara menetapkan arah dan tujuan pemenuhan hak ekosob. Tantangan yang muncul adalah pada kesesuaian standar dan cara yang dipergunakan untuk memenuhi hak. Negara tak jarang terjebak pada standar kaku yang justru membelenggu atau bahkan menutupi kebutuhan masyarakat yang sesungguhnya. Sebagai contoh dengan menetapkan bahwa pendidikan bertaraf internasional boleh diselenggarakan pada suatu negara berkembang, namun ternyata penetapan ini justru mendorong kapitalisasi pendidikan. Pendidikan dengan embel-embel internasional berbahasa Inggris, mendorong masyarakat untuk memilih sekalipun sangat mahal dan tidak sesuai. Di sisi lain, lulusan dari sekolah-sekolah noninternasional menjadi semakin terpinggir dari struktur sosial yang didominasi pendidikan taraf internasional baik untuk menunjang status. Dalam kondisi ini konsumsi atas pendidikan berubah melampaui kebutuhan aslinya, atau dalam pandangan Jean Baudrillard konsumsi digunakan untuk menuntupi situasi kelas yang sesungguhnya. ${ }^{40}$ Makna kebersesuaian hari ini memiliki tantangan terbesar dari dominasi simbol-simbol populer dan modern, dengan kemungkinan sangat tidak sesuai bagi masyarakat. Negara harus memaknai kebersesuaian juga pada konteks kebutuhan mendasar, yang merefleksikan suatu keliyanan dan keberpihakan pada kaum rentan sebagai pemahaman menyeluruh terhadap pemenuhan hak. ${ }^{41}$

38 Naning Mardiniah, et all, Meneropong Hak Atas Pendidikan dan Kesehatan Analisis Situasi Tiga Kabupaten: Indramayu, Sikka, dan Jayapura, (Jakarta: CESDA-LP3ES, 2005), hlm 27.

39 Ibid.

40 Haryatmoko, Membongkar Rezim Kepastian, (Yogyakarta: Pt Kanisius, 2016), hlm 67.

${ }^{41}$ Dalam konteks pembangunan ekonomi dapat pula menggunakan pendekatan yang hari ini tidak sekedar mengedepankan aspek pertumbuhan ekonomi. Pembangun inklusif dengan isu-isu kunci 
Pengujian terhadap teks hukum yang mampu merefleksikan standar pemenuhan hak, dilakukan oleh undang-undang yang terkait dengan hak ekosob di Indonesia. Pertama, pembahasan mengenai Undang-Undang Nomor 13 Tahun 2011 tentang Penanganan Fakir Miskin. Konsideran menimbang undang-undang ini menyebutkan bahwa tujuan undang-undang ini adalah memajukan kesejahteraan umum dan mencerdaskan kehidupan bangsa, memenuhi kebutuhan dasar yang layak kebijakan pembangunan nasional berpihak pada fakir miskin, integrasi dan koordinasi peraturan perundang-undangan penanganan fakir miskin. Tujuan tersebut akan bergantung pada konsistensi bahasa dalam pasal per pasal. Ada dua perhatian terhadap formulasi bahasa dalam undang-undang ini, yaitu tentang konsep penanganan kemiskinan dan tanggungjawab negara. Konsep penangangan kemiskinan akan dilihat sejauh mana kejelasan, dan ketegasan terhadap wilayah penanganan kemiskinan. Pada tataran tanggung jawab sejauh mana tanggung jawab yang dimiliki oleh negara, dalam mewujudkan tujuan penangangan kemiskinan sebagaimana disebutkan dalam konsideran.

Konsep dan tanggung jawab penanganan kemiskinan, mengalami ketidakjelasan rumusan, dan inkonsistensi makna dalam beberapa pasal. Hal ini dapat dilihat dalam beberapa pasal di bawah ini.

\begin{tabular}{|l|l|}
\hline $\begin{array}{l}\text { Formulasi dalam Undang-Undang } \\
\text { Penanganan Kemiskinan }\end{array}$ & $\begin{array}{l}\text { Analisa terhadap Ketidakjelasan dan } \\
\text { Inkonsistensi. }\end{array}$ \\
\hline $\begin{array}{l}\text { Pasal } 8 \text { ayat (1), menteri menetapkan } \\
\text { kriteria fakir miskin sebagai dasar untuk } \\
\text { melaksanakan penanganan fakir miskin. }\end{array}$ & $\begin{array}{l}\text { Rumusan disebutkan tentang kriteria, } \\
\text { namun kriteria yang dimaksud tidak ada. } \\
\text { Standar tidak mampu memenuhi kebutuhan } \\
\text { dasar, seperti apa misalnya. Negara harusnya } \\
\text { memiliki kesepakatan khusus tentang } \\
\text { kebutuhan yang dasar, sekalipun dalam } \\
\text { rumusan yang umum. }\end{array}$ \\
\hline $\begin{array}{l}\text { Pasal } 8 \text { ayat (6), verifikasi dan validasi } \\
\text { sebagaimana dimaksud pada ayat (5) } \\
\text { dikecualikan apabila terjadi situasi dan } \\
\text { kondisi tertentu yang baik secara } \\
\text { langsung maupun tidak langsung } \\
\text { mempengaruhi seseorang menjadi fakir } \\
\text { miskin. }\end{array}$ & $\begin{array}{l}\text { Situasi dan kondisi tertentu yang dimaksud } \\
\text { fasih tidak jelas seperti apa. Pada sisi ini hak } \\
\text { kemungkinan-kemungkinan tidak terduga. }\end{array}$ \\
\hline $\begin{array}{l}\text { Pasal } 9 \text { ayat (l), seorang fakir miskin yang } \\
\text { belum terdata dapat secara aktif } \\
\text { mendaftarkan diri kepada lurah atau } \\
\text { kepala desa atau nama lain yang sejenis di } \\
\text { tempat tinggalnya. }\end{array}$ & $\begin{array}{l}\text { Tuntutan tanggung jawab aktif ada pada } \\
\text { fakir miskin yang tidak terdaftar. Lalu } \\
\text { bagaimana kewajiban negara, untuk } \\
\text { melakukan pendataan ulang secara aktif, } \\
\text { secara harus dipahami fakir miskin seringkali } \\
\text { merupakan pihak yang terbatas dari akses. }\end{array}$ \\
\hline
\end{tabular}

seperti: kemiskinan, partisipasi, kolaborasi, dan jaringan kerja mulai menjadi alternatif dalam perspektif pembangunan ekonomi. Lihat Tulus Tambunan, Pembangunan Ekonomi Inklusif Sudah Sejauh Mana Indonesia, (Jakarta: LP3ES, 2016), hlm 15. 


\begin{tabular}{|c|c|}
\hline & $\begin{array}{l}\text { Negara harusnya mempersiapkan langkah } \\
\text { aktif untuk mengakomodir kebutuhan } \\
\text { tentang pendataan, dan jangan sampai di } \\
\text { kemudian hari hak yang tidak sampai } \\
\text { dikarenakan tidak tersedianya akses oleh } \\
\text { negara. }\end{array}$ \\
\hline $\begin{array}{l}\text { Pasal } 9 \text { ayat (2), kepala keluarga yang } \\
\text { telah terdaftar sebagai fakir miskin wajib } \\
\text { melaporkan setiap perubahan data } \\
\text { anggota keluarganya kepada lurah atau } \\
\text { kepala desa atau nama lain yang sejenis di } \\
\text { tempat tinggalnya. }\end{array}$ & $\begin{array}{l}\text { Perubahan data turut dibebankan kepada } \\
\text { keluarga, lalu bagaimana dengan peran dan } \\
\text { tanggung jawab negara. }\end{array}$ \\
\hline $\begin{array}{l}\text { Pasal } 12 \text { ayat (1), pemerintah dan } \\
\text { pemerintah daerah bertanggung jawab } \\
\text { mengembangkan potensi diri bagi } \\
\text { perseorangan, keluarga, kelompok, } \\
\text { dan/atau masyarakat. } \\
\text { Pasal } 12 \text { ayat (2) Pengembangan potensi } \\
\text { diri sebagaimana dimaksud pada ayat (1) } \\
\text { dilaksanakan melalui bimbingan mental, } \\
\text { spiritual, dan keterampilan. }\end{array}$ & $\begin{array}{l}\text { Potensi diri yang dimaksud dan } \\
\text { dikembangkan, tidak dijelaskan kadar } \\
\text { pengembangannya. Sekalipun pada pasal ini } \\
\text { diberikan kebebasan, namun kebebasan } \\
\text { harus memiliki standar untuk menilai sejauh } \\
\text { mana pemenuhan atas kebebasan memilih } \\
\text { potensi yang dimaksud. Lebih lanjut } \\
\text { berkenaan dengan bimbingan yang dimaksud } \\
\text { pun tidak diuraikan. }\end{array}$ \\
\hline $\begin{array}{l}\text { Pasal } 13 \\
\text { Pemerintah dan pemerintah daerah } \\
\text { bertanggung jawab menyediakan bantuan } \\
\text { pangan dan sandang yang layak. }\end{array}$ & $\begin{array}{l}\text { Kelayakan seperti apa yang dimaksud, tidak } \\
\text { ada kelanjutan pembahasan tentang hal ini. } \\
\text { Dalam kondisi tertentu persoalan kelayakan, } \\
\text { akan berpotensi untuk disimpangi dengan } \\
\text { alasan seperti ketersediaan sumber daya, dan } \\
\text { masalah keuangan daerah yang tidak } \\
\text { mencukupi. }\end{array}$ \\
\hline $\begin{array}{l}\text { Pasal } 14 \\
\text { Pemerintah dan pemerintah daerah } \\
\text { bertanggung jawab menyediakan } \\
\text { pelayanan perumahan. }\end{array}$ & $\begin{array}{l}\text { Pelayanan yang dimaksud pun tidak } \\
\text { diberikan batasan dan kriteria. Hal ini } \\
\text { seminimal mungkin pemerintah dan pemda } \\
\text { menyediakan, maka telah telah dianggap } \\
\text { memenuhi pelayanan. }\end{array}$ \\
\hline $\begin{array}{l}\text { Pasal } 15 \text { ayat (1) } \\
\text { Pemerintah dan pemerintah daerah } \\
\text { bertanggung jawab menyelenggarakan } \\
\text { penyediaan pelayanan kesehatan, baik } \\
\text { dengan pendekatan promotif, preventif, } \\
\text { kuratif, maupun rehabilitatif. }\end{array}$ & $\begin{array}{l}\text { Perhatikan kata "baik dengan", menandakan } \\
\text { bahwa ada pilihan. Tanggung jawab yang } \\
\text { dimaksud dengan demikian pendeketan } \\
\text { pelayanan masih belum ditetapkan. }\end{array}$ \\
\hline $\begin{array}{l}\text { Pasal } 40 \text { ayat (l) } \\
\text { Pemerintah dan pemerintah daerah sesuai } \\
\text { dengan kewenangannya melakukan } \\
\text { pengawasan terhadap penyelenggaraan } \\
\text { penanganan fakir miskin } \\
\text { Pasal } 40 \text { ayat (2) }\end{array}$ & $\begin{array}{l}\text { Keberadaan pasal ini, memperlihatkan } \\
\text { inkonsistensi terhadap pasal-pasal } \\
\text { sebelumnya. Perihal pengawasan seharusnya } \\
\text { selaras dengan pasal-pasal yang mendalilkan } \\
\text { tentang tanggungjawab. }\end{array}$ \\
\hline
\end{tabular}


Pengawasan sebagaimana dimaksud pada
ayat (l) dilaksanakan sesuai dengan
ketentuan peraturan perundang-
undangan.

Ragam bahasa dari beberapa contoh pasal di atas, mengalami ketidakjelasan dan inkonsistensi ketika berkenaan dengan rumusan kriteria. Setiap tanggung jawab dan konsep yang diformulasikan tidak dilanjutkan dengan formulasi lainnya. Hal ini yang membuat konsep hak, hanya sampai pada pengakuan terhadapnya. Perlindungan dan pemenuhan hak sosial ekonomi, terhadap fakir miskin terbatas pada kemungkinan yang diciptakan bahasa.

Pembahasan akan penggunaan ragam bahasa, dalam jaminan hak dilanjutkan pada Undang-Undang Nomor 20 Tahun 2003 tentang Sistem Pendidikan Nasional (UU Sistem Pendidikan Nasional). Pasal 5 UU Sistem Pendidikan Nasional menyebutkan bahwa warga negara memiliki setidaknya 5 hak dalam pendidikan, yaitu mendapat pendidikan bermutu, pendidikan khusus bagi yang memiliki kelainan, layanan khusus bagi daerah terpencil dan terbelakang serta masyarakat adat terpencil, pendidikan khusus bagi kecerdasan dan bakat istimewa dan kesempatan meningkatkan pendidikan sepanjang hayat. ${ }^{42}$ Gagasan tentang hak yang disediakan, turut pula melihat pada konsistensi yagn diekspresikan bahasa dalam pasal-pasal lainnya. Berikut adalah contoh beberapa pasal terkait jaminan hak, yang ada di dalam UU Sistem Pendidikan Nasional.

\begin{tabular}{|c|c|}
\hline $\begin{array}{l}\text { Formulasi dalam Undang-Undang } \\
\text { Sistem Pendidikan Nasional }\end{array}$ & $\begin{array}{l}\text { Analisa terhadap Ketidakjelasan dan } \\
\text { Inkonsistensi }\end{array}$ \\
\hline $\begin{array}{l}\text { Pasal } 32 \\
\text { (l) Pendidikan khusus merupakan pendidikan } \\
\text { bagi peserta didik yang memiliki tingkat } \\
\text { kesulitan dalam mengikuti proses } \\
\text { pembelajaran karena kelainan fisik, } \\
\text { emosional, mental, sosial, dan/atau memiliki } \\
\text { potensi kecerdasan dan bakat istimewa. } \\
\text { (2) Pendidikan layanan khusus merupakan } \\
\text { pendidikan bagi peserta didik di daerah } \\
\text { terpencil atau terbelakang, masyarakat adat } \\
\text { yang terpencil, dan/atau mengalami bencana } \\
\text { alam, bencana sosial, dan tidak mampu dari } \\
\text { segi ekonomi. } \\
\text { (3) Ketentuan mengenai pelaksanaan } \\
\text { pendidikan khusus dan pendidikan layanan } \\
\text { khusus sebagaimana dimaksud pada ayat (l) } \\
\text { dan ayat (2) diatur lebih lanjut dengan } \\
\text { peraturan pemerintah. }\end{array}$ & $\begin{array}{l}\text { Ketentuan dalam pasal ini hanya bentuk } \\
\text { pengulangan terhadap ketentuan dalam Pasal } 5 \\
\text { UU Sisdiknas. Mekanisme maupun kriteria } \\
\text { pendidikan khusus dan layanan khusus tidak } \\
\text { diberikan. Operasional dari pasal ini, sangat } \\
\text { bergantung dari pengaturan lebih lanjut dalam } \\
\text { Peraturan Pemerintah. Hal ini membuka ruang } \\
\text { ketidakpastian, terhadap jaminan hak pendidikan } \\
\text { khusus maupun layanan khusus. }\end{array}$ \\
\hline
\end{tabular}

42 Pasal 5 UU No 20 Tahun 2003 tentang Sistem Pendidikan Nasional. 


\begin{tabular}{|l|l|}
\hline Pasal 34 & Perhatikan kata "dapat", dalam ayat (l). Kata \\
(1) Setiap warga negara yang berusia 6 tahun & dapat merepresentasikan kemungkinan bisa iya \\
dapat mengikuti program wajib belajar. & mengikuti ataupun tidak mengikuti. Adapun \\
(2) Pemerintah dan pemerintah daerah & knsekuensinya adalah dapat memilih ikut \\
menjamin terselenggaranya wajib belajar & ataupun tidak dalam pendidikan. Negara \\
minimal pada jenjang pendidikan dasar & harusnya bisa menjamin dengan tegas, hingga \\
tanpa memungut biaya. & pada tindakan affirmatif untuk memaksa pihak- \\
& pihak yang bertanggungjawab dalam pemenuhan \\
& hak atas pendidikan bagi anak. Pada ayat (2) \\
& terlihat inkonsistensi formulasi bahasa. "Wajib \\
& belajar" disebutkan sebagai keharusannya \\
& jaminan pendidikan warga negara Indonesia. \\
& Namun ditambahkan klausul minimal pada \\
& jenjang pendidikan dasar tanpa pemungutan \\
biaya. Lalu bagaimana komitmen akan wajib \\
belajarnya.
\end{tabular}

Dari tabel di atas, terlihat bahwa orientasi penggunaan kata dan pilihan kata belum optimal untuk menjamin pemenuhan hak. Fungsi bahasa masih digunakan untuk menampilkan dan mengekspresikan aspek formal saja. Kebutuhan pada pemenuhan hak ekosob menuntut pada bahasa yang bukan hanya mengungkapkan pembagian tanggung jawab dan pihak-pihak yang berhak. Namun keberadaan bahasa dimaksudkan sebagai instrumen yang mampu menjalin kebutuhan dan kepentingan pemegang hak, dalam keberpihakan sekaligus menjamin keberlanjutan nilai-nilai dasar hak ekosob, seperti kebebasan, keteraksesan, ketersediaan, dan ketersesuaian dalam kerangka yang intergratif.

\section{KESIMPULAN}

Kerangka regulasi pemenuhan hak sosial-ekonomi berhubungan dengan dimensi formal dan teknis. Prinsip pengakuan, perlindungan, dan pemenuhan hak tidak dapat begitu saja muncul dalam kerangka regulasi. Proses bertahap harus dilalui oleh prinsip, untuk sampai pada konsep kerangka regulasi. Prinsip harus diolah ke dalam standar-standar, 
lalu dijelaskan melalui definisi dan klasifikasi. Dialektika teknis-formal ini kemudian direfleksikan dalam bahasa. Bahasa dalam kerangka regulasi menggambarkan komitmen negara dalam mengawal hak seringkali tidak konsisten. Kegagalan ini menjadikan pemenuhan hak tidak secara optimal direfleksikan tiap pasal dalam kerangka regulasi. Sebagai contoh dalam UU Penanganan Fakir Miskin dan Sistem Pendidikan Nasional, bahasa mengaburkan beberapa poin tanggung jawab negara. Tanggung jawab negara menjadi tidak operasional, dalam memenuhi tujuan pemenuhan hak sosial ekonomi, dan budaya. Kondisi ini muncul dikarenakan bahasa hanya diposisikan dalam formalitas yang memaksa dan mengarahkan. Bahasa dalam teks hukum harus diposisikan sebagai bahasa yang responsif dan berpihak kepada pemegang hak.

Hal ini diwujudkan dengan keberadaan bahasa yang mampu merefleksikan dan mentransformasikan dalam standar-standar pemenuhan hak ekobsob. Pertama, kebebasan yang disertai tanggung jawab aktif dari negara, dan kebebasan yang mampu mengawal pemegang hak menuju kemandirian untuk meningkatkan kualitas hidup. Kedua, bahasa yang mampu mempertegas ketersediaan kebutuhan dan fasilitas dalam pemenuhan hak. Ketiga, keteraksesan yang tidak hanya membuka ruang persaingan bebas, namun keteraksesan dengan komitmen pemenuhan hak yang merespon kebutuhan bagi kaum rentan dan terpinggirkan. Keempat, bahasa harus merefleksikan kebersesuaian berdasarkan praktik dan kaidah yang berlaku di masyarakat bukan sekedar merfleksikan simbol-simbol dominan, namun juga merfleksikan suatu keliyanan dan keberpihakan kepada kaum rentan sebagai pemahaman menyeluruh terhadap pemenuhan hak.

\section{DAFTAR PUSTAKA}

Amartya Sen, "Element of a Theory of Human Rights" (2004) 32: 4 Philosophy and Public Affairs.

Andrei Marmor, Social Convention From Language to Law, (New Jersey: Princetown University Press, 2009).

Andrew Halpin, Language, Truth and Law, dalam Michael Freeman dan Fiona Smith, Law and Language Current Legal Issue Volume 15, (United Kingdom: Oxford University Press, 2013).

B Arief Sidharta, Logika Sebuah Langka Mengenal Medan Telaah, (Bandung: Refika Aditama, 2008).

Christopher Hutton, Language, Meaning and The Law, (Edinburg: Edinburg University Press, 2009).

Deklarasi Universal Hak-Hak Asasi Manusia.

Ernesto Laclau, Deconstruction,Pragmatism, and Hegemony, dalam Simo Crithley et all, Deconstruction and Pragmatism, (New York: Routledge, 1996). 
Frans Magnis Suseno, Etika Politik Prinsip Moral Dasar Kenegaraan Moderen, cetakan ke 8, (Jakarta: Pt Gramedia Pustaka, 2016).

G.W Paton, Textbook of Jurisprudence, second edition, (London: Oxford University Press, 1955).

Hans Kolstad, "The Welfare State System Confronted with The Human Rights Principles" (2015) 37:2 Social Development Issues-International Consortium for Social Development.

Haryatmoko, Membongkar Rezim Kepastian, (Yogyakarta: Pt Kanisius, 2016).

HLA Hart, Concept of Law (Second Edition), (Oxford: Oxford University Press, 1997).

http://www.plainlanguage.gov/populartopics/regulations/aba.cfm.

Irving M Copi, Carl Cohen, Kenneth McMahon, Introduction to Logic, Pearson New International Edition, (United State: Pearson Education Limited, 2014).

James Griffin, On Human Rights, (New York: Oxford University Press, 2008).

JJ. Brugink, Refleksi Tentang Hukum Pengertian-Pengertian Dasar dalam Teori Hukum, penerjemah: B. Arief Sidharta, (Bandung: Citra Aditya Bakti).

Joseph Raz, Authority of Law Essay on Law and Morality, (New York: Oxford Press, 1979)

Komentar Umum Konvenan Internasional Hak Sipil Politik-Hak Ekonomi Sosial Budaya, (Jakarta: Komnas Ham, 2009).

Kovenan Internasional Hak Sosial Ekonomi dan Budaya.

Marcus Arvan, A Better, "Dual Theory of Human Rights" 45: 1 Philosophical Forum.

Meuwissen, Tentang Pengembangan Hukum, Ilmu Hukum, Teori Hukum, dan Filsafat, terjemahan B Arief Sidharta, (Bandung: Refika Aditama, 2013).

Naning Mardiniah, et all, Meneropong Hak Atas Pendidikan dan Kesehatan Analisis Situasi Tiga Kabupaten: Indramayu, Sikka, dan Jayapura, (Jakarta: CESDA-LP3ES, 2005).

Olga Burukina, "Legal Language: A Realm of Contradiction" (2012) 4: 2 Journal Contemporary Readings in Law and Social Justice.

Sabine C Carey, Mark Gibney, dan Steven C Poe, The Politics of Human Rights The Quest of Dignity, (New York: Cambridge University Press, 2010).

Sajtipto Raharjo, Penafsiran Hukum yang Progresif, Makalah untuk mahasiswa PDIH UNDIP dalam Mata kuliah Ilmu Hukum dan Teori Hukum, Pleburan, 20 Januari 2005.

Satjipto Raharjo, Ilmu Hukum, (Bandung: Citra Aditya Bakti, 2014).

Shareen Hertel dan Lanse Minkler, Economic Right The Terrain dalam Shareen Hertel dan Lanse Minkler, Economic Rights Conceptual, Measurement, and Policy Issue, (United State: Cambridge University Press, 2007).

Soetandyo Wignjosoebroto, Pergeseran Paradigma dalam Kajian-Kajian Sosial dan Hukum, (Malang: Setara Press, 2013).

Tulus Tambunan, Pembangunan Ekonomi Inklusif Sudah Sejauh Mana Indonesia, (Jakarta: LP3ES, 2016).

Undang Nomor 20 Tahun 2003 tentang Sistem Pendidikan Nasional. 
Undang-Undang Nomor 12 Tahun 2011 tentang Pembentukan Peraturan Perundangundangan.

Undang-Undang Nomor 13 Tahun 2011 tentang Penanganan Fakir Miskin Undang.

United Nation, Economic Cultural and Social Rights Handbook for National Human Rights Institution, (New York: United Nation, 2005). 